\title{
Potential carbon sequestration and nitrogen cycling in long-term organic management systems
}

\author{
Arnab Bhowmik ${ }^{1,2}$, Ann-Marie Fortuna ${ }^{* 3,4}$, Larry J. Cihacek ${ }^{1}$, Andy I. Bary ${ }^{5}$, Patrick M. Carr ${ }^{6}$ and \\ Craig G. Cogger ${ }^{5}$ \\ 'Department of Soil Science, North Dakota State University, Fargo, North Dakota, USA. \\ ${ }^{2}$ Department of Ecosystem Science and Management, The Pennsylvania State University, University Park, \\ Pennsylvania, USA. \\ ${ }^{3}$ Formerly of the Department of Soil Science, North Dakota State University, Fargo, North Dakota, USA. \\ ${ }^{4}$ Adjunct Department of Crop and Soil Science, Washington State University, Pullman, Washington, USA. \\ ${ }^{5}$ Department of Crop and Soil Science, Washington State University, Puyallup, Washington, USA. \\ ${ }^{6}$ Montana State University, Central Agricultural Research Center, Moccasin, Montana, USA. \\ *Corresponding author: afortuna@wsu.edu.
}

Accepted 14 October 2016; First published online 12 January 2017

Research Paper

\begin{abstract}
The fertility and soil health of organic agroecosystems are determined in part by the size and turnover rate of soil carbon (C) and nitrogen $(\mathrm{N})$ pools. Our research contrasts the effects of best management practices (BMP) (reduction in soil disturbance, addition of organic amendments) on $\mathrm{C}$ and $\mathrm{N}$ cycling in soils from two field sites representing five organic agroecosystems. Total soil organic $\mathrm{C}(\mathrm{SOC})$, a standard measure of soil health, contains equal amounts of biologically and non-biologically active $\mathrm{C}$ that is not associated with release of mineral $\mathrm{N}$. A three-pool first-order model can be used to estimate the size and turnover rates of $\mathrm{C}$ pools but requires data from a long-term incubation. Our research highlights the use of two rapid $\mathrm{C}$ fractions, hydrolysable and permanganate $(0.02 \mathrm{M})$ oxidizable $\mathrm{C}$, to assess shifts in biologically active $\mathrm{C}$. Adoption of BMP in organic management systems reduced the partitioning of $\mathrm{C}$ to the active pool while augmenting the slow pool $\mathrm{C}$. These pools are associated with potentially mineralizable $\mathrm{N}$ supplied by residues, amendments and soil organic matter affecting the concentration and release of mineral $\mathrm{N}$ to crops. Our data show that minimizing disturbance (no tillage, pasture) and mixed compost additions have the potential to reduce carbon dioxide emissions while enhancing slow pool $\mathrm{C}$ and or its turnover, a reservoir of nutrients available to the soil biota. Use of these rapid, sensitive indicators of biological $\mathrm{C}$ activity will aid growers in determining whether a BMP fosters nutrient loss or retention prior to shifts in total SOC.
\end{abstract}

Key words: carbon, soil carbon pools, permanganate oxidizable carbon, hydrolyzable carbon, slow pool carbon, soil health, organic management practices, no tillage, mixed compost, nitrogen mineralization

\section{Introduction}

Organic agroecosystems promote biological cycles and soil biological activity such that nitrogen $(\mathrm{N})$ and carbon (C) losses are reduced while $\mathrm{N}$ utilization and $\mathrm{C}$ sequestration are enhanced (Johnson et al., 2007; Berthrong et al., 2013; Bowles et al., 2015; Bhowmik et al., 2016). These systems mimic natural ecosystems in that $\mathrm{C}$ and $\mathrm{N}$ are bound or coupled together in the form of organic constituents that include soil organic matter (SOM), the decomposition of which controls a significant proportion of $\mathrm{N}$ mineralization and soil fertility
(Berthrong et al., 2013). There is a growing body of literature that suggests that soil health, 'the capacity of a specific kind of soil to function, within natural or managed ecosystem boundaries, to sustain plant and animal productivity, maintain or enhance water and air quality, and support human health and habitation' (Karlen et al., 1997), can be improved by adopting organic management practices (Bhowmik et al., 2016).

Most organic management systems integrate several best management practices (BMP) that foster the accumulation of soil $\mathrm{C}$ and $\mathrm{N}$, indicators of soil health. Improvements in soil health are the result of long-term 
adoption of BMP in organic systems (Drinkwater et al., 1998; Fließbach et al., 2007; Bhowmik et al., 2016). Additions of animal manures, the retention of residues from cash and cover crops and reduced soil disturbance contribute to SOM reserves. Increases in SOM are associated with improvements in soil health such as increases in soil $\mathrm{C}$ stocks and serves as a source of mineral $\mathrm{N}$ and other nutrients (Gattinger et al., 2012; Lucas \& Weil, 2012). Nitrogen management in organic production systems is challenging as organic agricultural systems are typically N limited (Gaskell and Smith, 2007). Thus, indicators of soil health could be used by organic growers to verify that biological $\mathrm{C}$ and $\mathrm{N}$ are coupled in a given organic management system. However, current indicators of soil health such as soil organic C (SOC) contain $\mathrm{C}$ that is not associated with nutrient turnover and therefore does not reflect the initial seasonal and short-term ( $>3-5$ year) changes in the turnover rates and quantity of labile $\mathrm{C}$ fractions that are associated with the implementation of BMP (Janzen et al., 1998). McLauchlan and Hobbie (2004) address the above concern in the context of choosing measures of labile $\mathrm{C}$ pools that increase sufficiently as SOC increases. They suggest microbial biomass is too small a labile $\mathrm{C}$ fraction and that indicators such as permanganate oxidizable carbon (POXC) that contain a greater portion of labile $\mathrm{C}$ and have a longer mean residence time may prove to be better indicators of changes in SOC and in particular labile fractions of SOC.

Stocks of $\mathrm{C}$ contained in SOM are often defined as pools that vary in their decomposition rate due to their biochemical composition. The BMP affect SOC and the further partitioning of $\mathrm{C}$ into different pools of variable turnover rates. The $\mathrm{CO}_{2}-\mathrm{C}$ evolved from long-term 360 day incubations, total SOC and resistant or non-hydrolyzable $\mathrm{C}$ can be used to estimate the size of the active pool of $\mathrm{C}$ (turnover of days); slow pool C (turnover of years); and resistant pool C (no significant turnover rate) via a three pool nonlinear model (Paul et al., 1999). The proportion of each of the different $C$ pools present in the soil provides important information with respect to soil health and fertility (Fortuna et al., 2003).

The active and slow pools of $\mathrm{C}$ in soil are directly affected by BMP (Motavalli et al., 1994; Paul et al., 1999; Fortuna et al., 2003; Jha et al., 2012). The active pool of $\mathrm{C}$ at a $0-30 \mathrm{~cm}$ depth represents $\leq 5 \%$ of total SOC, turns over in a growing season and can be equated to seasonal carbon dioxide $\left(\mathrm{CO}_{2}\right)$ emissions in the field. This pool consists of easily decomposable $\mathrm{C}$ compounds (simple sugars, organic acids and microbial metabolites) that provide an important source of energy to microorganisms (Fortuna et al., 2003; Iqbal et al., 2009). The slow pool of $C$ at the same depth consists of structural plant residues and physically stabilized carbon and effects the nutrient buffering capacity of soils (Fortuna et al., 2003). The slow C pool contains $\sim 40$ $50 \%$ of total SOC and turns over in years. The active plus slow $\mathrm{C}$ represents hydrolyzable $\mathrm{C}$. The non-hydrolyzable $\mathrm{C}$ fraction can be measured via the acid hydrolysis procedure and contains $\sim 40-50 \%$ of total SOC at a 0-30 cm (Paul et al., 1997). It is mainly comprised of lignin and chemically stabilized C (Buyanovsky et al., 1994; Paul et al., 1999). This fraction improves soil tilth but does not contribute $\mathrm{C}$ for microbial respiration (Six et al., 2002). Despite the broad acceptance of these techniques to estimate $\mathrm{C}$ pools and turn-over rates, they are time consuming and require resources that prohibit their use as a standard measure of soil health or fertility index. Therefore, there is a need to correlate the turnover rates obtained from methods such as long-term $\mathrm{C}$ incubations with other rapid measures of labile soil $\mathrm{C}$ fractions (McLauchlan and Hobbie, 2004). In this paper, we illustrate the value of correlating several rapid measures of soil $\mathrm{C}$ that include SOC, hydrolyzable $\mathrm{C}$ and POXC measurements with estimates of active and slow pools of $\mathrm{C}$ dervived from a 360 day incubation.

There is a plethora of published research illustrating the value and ease of using POXC as an index of soil health (Melero et al., 2009a, b; Lopez-Garrido et al., 2011, 2014; Culman et al., 2012). In contrast, there is a dearth of information with respect to its relationship with other fractions and pools of SOC. A current initiative in organic agriculture research is to employ indicators of soil health to reveal useful information about the biological function and fertility of organic farming systems. In furtherance of this goal, a number of research groups have attempted to develop or apply labile soil $\mathrm{C}$ tests such as hydrolyzable $\mathrm{C}$ and POXC as short-term indicators of long-term changes in soil health and fertility (Weil et al., 2003; Dou et al., 2008; Culman et al., 2012).

The biogeochemical cycling of $\mathrm{C}$ and $\mathrm{N}$ in organic systems is complex, and the range of existing organic management systems is diverse (Franzluebbers, 2005; Johnson et al., 2007). Although biological indicators of soil health are dynamic measures of biological cycles and soil biological activity, there are few data sets available that compare such measures across different organic management systems (Azeez, 2009). The objective of our research was to determine if coupling a current indicator of soil health (SOC) with novel indicators representing biologically active $\mathrm{C}$ fractions (hydrolyzable $\mathrm{C}, \mathrm{POXC}$ ) could improve assessment of the effects of BMP (mixed compost and minimizing soil disturbance) on soil fertility ( $\mathrm{C}$ and $\mathrm{N}$ cycling) in five diverse US Department of Agriculture (USDA) organic certified farming systems.

\section{Materials and Methods}

Long-term Organic Field Sites Two USDA certified organic experimental field sites, The Long-term Organic Tillage Systems (LOTS) study and the Long-term Organic Vegetable Systems Experiment (IFSYS), were 
used to evaluate the effects of BMP on $\mathrm{C}$ and $\mathrm{N}$ cycling. The five organic management systems chosen from the two experimental sites provided contrasts among treatments receiving varying levels of disturbance and organic $\mathrm{C}$ and $\mathrm{N}$ additions in the form of animal manure and cover crops. Growing degree days were calculated for each field crop using the Baskerville-Emin method (Andresen, 2010) using a base temperature of 4.4 and $7.2^{\circ} \mathrm{C}$ for LOTS (field pea, Pisum sativum L. ssp. sativum) and IFSYS (Delicata squash, Cucurbita реро) plots, respectively.

The LOTS tillage plots were established in 2010 on Reeder-Farnuf loams (fine-loamy, mixed, superactive, frigid, typic Argiustolls) at the North Dakota State University Dickinson Research and Extension Center, USA $\left(46^{\circ} 53^{\prime} \mathrm{N}, 102^{\circ} 49^{\prime} \mathrm{W}\right.$; elevation $\left.760 \mathrm{~m}\right)$. The soil had a $\mathrm{pH}\left(\mathrm{H}_{2} \mathrm{O}\right)$ of $6.7, \mathrm{EC}$ of $0.85 \mathrm{dS} \mathrm{m}^{-1}$ and contained $30 \%$ sand, $47 \%$ silt and $23 \%$ clay. Soils were collected in 2014 from two treatments, clean and no tillage (8 field plots) from the LOTS experiment. The clean tillage plots were cultivated with a tandem disc to a $10 \mathrm{~cm}$ soil depth. Seeding with a low-disturbance planter was the only event in the no tillage plots that resulted in soil disturbance. The plots were $30 \times 9 \mathrm{~m}^{2}$ and were arranged as a randomized complete block with each treatment replicated four times. A detailed description of the 5year rotation and all field operations can be found in Supplementary Table S1. Weeds were suppressed by preplant tillage in clean tillage plots or by a pre-plant application of $20 \%$ acetic acid dissolved in water to no tillage plots. Weed management was combined with grazing by sheep (Ovis aries) and the use of cover crops. In this paper, soils were collected in 2014 in the pea plots after harvest and grazing but prior to planting hairy vetch (Vicia villosa Roth).

The IFSYS organic vegetable systems experiment was established in 2003 as a USDA certified organic field plot at the Washington State University (WSU) Puyallup Research and Extension Center, USA (47 $11^{\prime}$ $24^{\prime \prime} \mathrm{N}, 122^{\circ} 19^{\prime} 48^{\prime \prime} \mathrm{W}$; elevation $13 \mathrm{~m}$ ). The experiment is located on an alluvial soil classified as a Puyallup fine sandy loam (coarse-loamy over sandy, isotic over mixed, mesic Fluventic Haploxerolls) (Cogger et al., 2016). The soil had a pH $\left(\mathrm{H}_{2} \mathrm{O}\right)$ of 6.4 , EC of $0.46 \mathrm{dS} \mathrm{m}^{-1}$ and contained $51 \%$ sand, $40 \%$ silt and $9 \%$ clay. Soils were collected in 2014 from three treatments (12 field plots) in the IFSYS experiment. The treatments included: (1) annual fall-seeded cover crop-vegetable rotation, mixed compost amendment; (2) annual fall-seeded cover crop-vegetable rotation, broiler litter amendment; (3) 3-year pasture-vegetable rotation with amendment. See Supplementary Table S2 for a detailed description of field operations and management. The plots $6.1 \times$ $15.2 \mathrm{~m}^{2}$ were arranged as a randomized complete block with four field replicates for each treatment.

Amendments were applied to the plots in spring after the mowing of the cover crop. The N-rich broiler litter
(4-6 $\mathrm{Mg} \mathrm{ha}^{-1}$ year $^{-1}$ ) consisted mainly of partially composted manure and softwood shavings. The broiler litter was applied after 6-7 weeks of mixed composting in a turned pile. The C-rich mixed compost was applied at 14-18 Mg ha ${ }^{-1}$ year $^{-1}$ and was comprised of dairy manure solids, animal bedding (straw and sawdust with manure), yard debris and small amounts of broiler litter and fish waste. The mixed compost was applied after 24-28 weeks of composting and curing in an aerated static pile. The available $\mathrm{N}$ supplied by both the amendments were comparable (Cogger et al., 2016). However, the mixed compost supplied 2-5 times more $\mathrm{C}$ than the broiler litter. The amount of $\mathrm{C}$ and $\mathrm{N}$ added as mixed compost and broiler litter from 2003 to 2014 can be found in Supplementary Table S3. The pasture rotation was maintained for 30 months followed by 6 months of vegetable cash crop. The pasture plots consisted of a fall planted mixture of red clover (Trifolium pretense), annual ryegrass (Lolium multiflorum Lam.) and perennial ryegrass (Lolium perenne L.). Sheep and poultry (Gallus gallus domesticus) are raised on the pastures in the rotational grazing system. In this paper, soil samples were collected in 2014 from fall-seeded cover plots following Delicata squash, while pasture plots were in the 14th month of the pasture rotation.

\section{Soil sampling, treatment and storage}

Twelve random samples were taken at two depths (0-15 and $15-30 \mathrm{~cm}$ ) from each of the four field plot replicates within a $15 \times 6 \mathrm{~m}^{2}$ area with a soil probe $(2.5-\mathrm{cm}$ diam.) at the Puyallup, WA and Dickinson, ND sites in November 2014. The 12 soil cores from each field plot replicate at a given depth were composited and mixed to provide a single sample. The soil bulk density was determined using a hammer driven bulk density core sampler $(6 \mathrm{~cm}$ deep $\times 5.4 \mathrm{~cm}$ diameter) (Grossman and Reinsch, 2002). Soil samples were analyzed for gravimetric moisture and initial inorganic $\mathrm{N}$ content $\left(\mathrm{NH}_{4}^{+}+\mathrm{NO}_{3}^{-}\right)-\mathrm{N}$ extracted with $2 \mathrm{M} \mathrm{KCl}$ and analyzed using an auto-analyzer (SEAL Analytical Inc, Mequon, WI). A portion of the remaining field moist soil samples were passed through a $2 \mathrm{~mm}$ sieve and stored at $4^{\circ} \mathrm{C}$ for use in a 360 day $\mathrm{N}$ incubation. The remaining soil was air dried and passed through a 2-mm sieve after which the soil was used to conduct a 360 day $\mathrm{C}$ incubation and to determine the SOC, POXC and resistant $\mathrm{C}$ for each field plot treatment and depth.

\section{Total SOC and its fractions}

Air dried soil samples were passed through a 100 mesh sieve prior to analysis for SOC, POXC and acid hydrolysis. The non-hydrolyzable $\mathrm{C}$ fraction in soil also referred to as the resistant carbon pool was isolated via acid hydrolysis (Paul et al., 2001). After the digested soil samples were dried at $30^{\circ} \mathrm{C}$ overnight, they were ground 
to pass through a 100 mesh sieve. Total $\mathrm{C}$ in whole soil and non-hydrolyzable $\mathrm{C}$ was measured by dry combustion (Skalar Analytical B.V., Netherlands). The hydrolyzable $\mathrm{C}$ fraction was calculated by subtracting the non-hydrolyzable C from the SOC (Dou et al., 2008). The POXC was determined by a procedure modified by Culman et al., 2012 and derived from the procedure of Weil et al. (2003). The PROC GLM procedure of SAS 9.4 (SAS Institute, Cary, NC) was used to determine the effect of treatments on SOC, POXC and hydrolyzable C. The LSMEANs procedure was used to compare the least squares' means of organic treatments within a field site (LOTS, IFSYS) and across soil depth $(P=0.05$ level of significance).

\section{Long-term carbon incubation}

Soil samples were incubated for 360 day in a laboratory incubator (Precision TM Low Temperature BOD Refrigerated Incubator, Thermo Fischer Scientific Inc., Waltham, MA) at $25^{\circ} \mathrm{C}$ and $60 \%$ water-filled pore space (WFPS) (Fortuna et al., 2003). Soils from each treatment and depth contained four replicates. The total number of samples was 24 ( 3 treatments $\times 4$ field reps $\times 2$ depths) for IFSYS and 16 ( 2 treatments $\times 4$ field reps $\times 2$ depths) for LOTS. Samples were incubated in $128 \mathrm{~g}$ sterile specimen vials containing field moist soil equivalent to $50 \mathrm{~g}$ on a dry wt. basis and packed to a bulk density of 1.1 and $1.0 \mathrm{~g} \mathrm{cc}^{-1}$ for the LOTS and IFSYS plots, respectively.

Specimen vials were placed into $935 \mathrm{~cm}^{3}$ glass canning jars fitted with lids containing septa for gas sampling. The headspace of each replicated treatment was sampled successively for $\mathrm{CO}_{2}$ at time zero and days $3,7,14,21,28,42$, 56, 70, 90, 120, 150, 180, 210, 240, 270, 300, 330 and 360 . After each gas sampling the headspace was aired, and the specimen cups were weighed and the moisture content was adjusted to $60 \%$ WFPS. The total number of gas samples was 456 ( 3 treatments $\times 4$ field reps $\times 2$ depths $\times$ 19 time intervals) for IFSYS and 304 ( 2 treatments $\times 4$ field reps $\times 2$ depths $\times 19$ time intervals) for LOTS. The $\mathrm{CO}_{2}$ samples were analyzed on an Infrared Gas Analyser (IRGA, LI-COR 830). A set of certified $\mathrm{CO}_{2}$ standards were run and internal standards and blank vials were sampled at each time interval. The PROC GLM procedure was used to determine the effect of organic management treatments on cumulative $\mathrm{CO}_{2}-\mathrm{C}$ evolved. The LSMEANs procedure was used to compare the least squares' means of organic treatments within a field site (LOTS, IFSYS) and across soil depth ( $P=0.05$ level of significance).

\section{Data fitting for determining carbon pools}

A three pool nonlinear model in SAS NLIN was fitted in order to estimate the size of the active and slow pools of $\mathrm{C}$ and their turnover rates (Fortuna et al., 2003). The active fraction $\left(C_{a}\right)$ was estimated from the model by measuring the amount of $\mathrm{CO}_{2}-\mathrm{C}$ evolved from incubation vessels. The non-hydrolyzable $\mathrm{C}$ was used to estimate the resistant fraction $\left(C_{r}\right)$ (Paul et al., 2001). A two-pool first-order constrained model, including an interval correction adapted from Ellert and Bettany (1988), was used to estimate the size and turnover rates of individual pools as described below and in Fortuna et al. (2003).

$$
\begin{aligned}
& C_{(\min )}=C_{a}\left(e^{\left(-k a^{*} t 1\right)}-e^{\left(-k a^{*} t 1-k a^{*} t 2\right)}\right)+ \\
& \left(C_{t 1}-C_{r 1}-C_{a 1}\right) \times\left(e^{\left(-k s^{*} t 1\right)}-e^{\left(-k s^{*} t 1-k s^{*} t 2\right)}\right)
\end{aligned}
$$

Curve fitting of the $\mathrm{CO}_{2}-\mathrm{C}$ evolved per unit time; $\mathrm{C}$ (min), was performed using the NLIN procedure of SAS 9.4 (SAS Institute, Cary, NC). $C_{a}$, ka $=$ active pool; $C_{s}$, ks = slow pool; $C_{r}=$ resistant pool; $t_{1}=$ start of sample interval; $t_{2}=$ end of sample interval. The slow pool is defined as $C_{s}=\left(C_{t 1}-C_{r 1}-C_{a 1}\right)$ where $C_{t 1}$ is the total soil organic $\mathrm{C},\left(C_{r}\right)$ the resistant pool and $C_{a 1}$, the initial active pool of $\mathrm{C}$ at time zero. The resistant fraction $\left(C_{r}\right)$ is equated to the total $\mathrm{C}$ content of the residue of acid hydrolysis (Paul et al., 2001). The size of the active pool $\left(C_{a}\right)$, decomposition rate of the active (ka) and slow pools (ks), as well as mean residence times (MRT) of the active $(1 / \mathrm{ka})$ and slow pools $(1 / \mathrm{ks})$, was calculated from the model. The laboratory MRT at $25^{\circ} \mathrm{C}$ was scaled to an average field temperature $\left(10^{\circ} \mathrm{C}\right)$ by assuming a $Q_{10}$ of 2.8 (Katterer et al., 1998; Paul et al., 1999; Fortuna et al., 2003). The PROC GLM procedure of SAS 9.4 (SAS Institute, Cary, NC) was used to determine the effect of treatments on resistant C. The LSMEANs procedure was used to compare the least squares' means of organic treatments within a field site (LOTS, IFSYS) and across soil depth $(P=0.05$ level of significance).

\section{Long-term $N$ incubation}

The total soil $\mathrm{N}$ contained in soil samples used in the $\mathrm{N}$ incubation was determined using the Kjeldahl method (Bremner, 1960). A 360 day $\mathrm{N}$ incubation was conducted in the laboratory at $25^{\circ} \mathrm{C}$ and $60 \%$ WFPS (Fortuna et al., 2003) using fresh field moist soil sieved through a $2 \mathrm{~mm}$ mesh. For this purpose, $50 \mathrm{~g}$ soil samples in sets of four replicates per treatment plot per depth were weighed into $128 \mathrm{~g}$ sterile specimen vials and packed to a bulk density of 1.1 and $1.0 \mathrm{~g} \mathrm{cc}^{-1}$ for the LOTS and IFSYS plots, respectively. Each time interval required a separate set of samples due to the destructive sampling requirement for analysis of inorganic $\mathrm{N}$ at six separate time intervals on days: $7,14,90,150,210$ and 360 . The total number of samples was 144 (3 treatments $\times 4$ field reps $\times 2$ depths $\times 6$ time intervals) for IFSYS and $96(2$ treatments $\times 4$ field reps $\times 2$ depths $\times 6$ time intervals) for LOTS. Soil samples were aerated and maintained at $60 \%$ WFPS throughout the 360 day incubation.

A completely randomized two-factor factorial analysis of variance (ANOVA) was conducted using the MIXED procedure of SAS 9.4 (SAS Institute, Cary, NC) to 
Table 1. Measurements of soil organic carbon (SOC), cumulative $\mathrm{CO}_{2}$ mineralized and total nitrogen (N) for 0-30 cm soil depth.

\begin{tabular}{|c|c|c|c|c|c|}
\hline \multirow[b]{2}{*}{ Field site } & \multirow[b]{2}{*}{ Treatment } & \multirow{2}{*}{$\frac{\mathrm{SOC}}{\mathrm{MgC} \mathrm{ha}^{-1}}$} & \multicolumn{2}{|c|}{ Cumulative $\mathrm{CO}_{2}$ evolved ${ }^{I}$} & \multirow{2}{*}{$\begin{array}{l}\text { Total N } \\
\text { Mg N ha }\end{array}$} \\
\hline & & & $\mathrm{MgCha}$ & $\% \mathrm{SOC}$ & \\
\hline \multirow{5}{*}{$\begin{array}{l}\text { NDSU LOTS } \\
\text { (4 year) } \\
\text { WSU IFSYS } \\
\text { (11 year) }\end{array}$} & Clean tillage & $42.4 \mathrm{a}^{2}$ & $2.50 \mathrm{~b}$ & $6 \mathrm{a}$ & $2.69 \mathrm{a}$ \\
\hline & No tillage & $45.3 \mathrm{a}$ & $3.06 \mathrm{a}$ & $7 \mathrm{a}$ & $2.90 \mathrm{a}$ \\
\hline & Mixed compost & $73.9 \mathrm{~A}$ & $4.94 \mathrm{~A}$ & $7 \mathrm{~A}$ & $4.37 \mathrm{~A}$ \\
\hline & Broiler litter & $51.5 \mathrm{~B}$ & $3.80 \mathrm{~B}$ & $7 \mathrm{~A}$ & $2.74 \mathrm{~A}$ \\
\hline & Pasture & $45.9 \mathrm{~B}$ & $3.15 \mathrm{~B}$ & $7 \mathrm{~A}$ & $3.29 \mathrm{~A}$ \\
\hline
\end{tabular}

${ }^{I}$ Cumulative carbon dioxide $\left(\mathrm{CO}_{2}\right)$ evolved from a 360 day incubation at $25^{\circ} \mathrm{C}$ and $60 \%$ water-filled pore space.

2 ANOVA was run in SAS PROC GLM (SAS 9.4). Means within a column and field site with different letters are significantly different at $P=0.05$ by the LSMEANs procedure $(P=0.05$ level of significance). The two soil depths, $0-15$ and $15-30 \mathrm{~cm}$ were not significantly different from one another. Therefore the means are averaged across soil depths $0-30 \mathrm{~cm}$.

determine the effect of organic managements on the mineralizable $\mathrm{N}$ during the 360 day incubation, the mean separations were performed using least significant difference with the LSMEANs procedure at the $P=0.05$ level of significance. The linear bivariate relationships and the least square regression lines between individual soil $\mathrm{C}$ measurements (HC, POXC, SOC and cumulative $\mathrm{CO}_{2}$ evolved) and cumulative inorganic $\mathrm{N}$ mineralized (MinN) on day 90 were graphed using the SPSS 22 software package (IBM Corp., Armonk, NY). The linear bivariate relationships and the least square regression lines contained all five organic treatments replicated four times at two depths $n=40$.

\section{Results}

\section{Use of SOC and cumulative $\mathrm{CO}_{2}-\mathrm{C}$ evolved during a 360 day laboratory incubation to estimate the size and MRT of C pools}

The soils sampled in this experiment did not contain inorganic C. Soil taken from the mixed compost treatment in the IFSYS experiment had $30 \%$ more SOC relative to the broiler litter treatment and $38 \%$ more SOC than the pasture that received $\sim$ a third of the $\mathrm{C}$ inputs added to the two annual systems (Table 1). Differences in SOC were not detected between the clean and no tillage treatments in the LOTS study. No siginificant differences in SOC or the portion of SOC mineralized and evolved as $\mathrm{CO}_{2}-\mathrm{C}(6-7 \%)$ during the 360 day incubation were measured in soils taken from the two tillage managements on the LOTS experiment or among the soils taken from the organic IFSYS field site at $P=0.05$ level of significance.

During the 360 day laboratory incubation all of the $\mathrm{C}$ in the active pool and a limited portion of the slow pool was evolved as $\mathrm{CO}_{2}-\mathrm{C}$. During the early stages of the incubation, the $\mathrm{C}$ mineralized was derived largely from the active pool of $\mathrm{C}$ with a laboratory MRT ranging from 21 to 30 days (Table 2). The active pool comprised only $1 \%$ of the SOC in all five of the organic management systems and there was no significant difference in size and turnover rate of the active $\mathrm{C}$ pools among the treatments. In contrast, the slow pool and or its MRT varied among treatments. The size of the slow pool of $\mathrm{C}$ in the clean and no tillage treatments in the LOTS plots was comparable but the MRT was higher in the clean tillage treatment (Table 2). Addition of mixed compost to the IFSYS plots resulted in greater amounts of $\mathrm{C}$ in the slow pool relative to the broiler litter and pasture system but the percent of total $\mathrm{C}$ in the slow pool was higher in the broiler litter and pasture treatments relative to the mixed compost. The pasture had the longest estimated MRT while the mixed compost and broiler litter treatments had equivalent MRTs. Finally, application of mixed compost to the IFSYS field site contributed more to the resistant pool of $\mathrm{C}$ relative to broiler litter additions and pasture managemnt (Table 2).

The pasture and broiler litter treatments had comparable SOC, cumulative $\mathrm{CO}_{2}$ evolved, slow pool and resistant C. The pasture was tilled every 30 months after which the plots received an addition of an animal manure. Despite varitions in $\mathrm{C}$ due to management, total soil $\mathrm{N}$ concentrations were equivalent across all IFSYS treatments.

\section{Measurements of hydrolyzable $C$ and POXC}

In our study, the application of mixed compost decreased the proportion of hydrolyzable $\mathrm{C}$ in SOC relative to the broiler litter and pasture treatments (Table 3). The POXC fraction in this study represented $4 \%$ of the hydrolyzable $\mathrm{C}$ pool in the tillage treatments and nearly double $(7-6 \%)$ in the IFSYS plots. Our data reveal that POXC targets a more sensitive fraction of the SOC that represents the active $\mathrm{C}$ and a limited portion of slow pool C. Mean POXC values were significantly higher, not quite double in treatments where mixed compost was applied as compared with the treatment receiving broiler litter and the pasture system (Table 3). In contrast, no significant difference in the POXC fraction was observed in the clean versus no tillage LOTS plots. 
Table 2. Estimates of active, slow and resistant $\mathrm{C}$ pools and mean residence times $(\mathrm{MRT})^{1}$ for $0-30 \mathrm{~cm}$ soil depth as determined by a 360 day laboratory incubation.

\begin{tabular}{|c|c|c|c|c|c|c|c|c|c|c|c|}
\hline \multirow[b]{2}{*}{ Field site } & \multirow[b]{2}{*}{ Treatment } & \multicolumn{4}{|c|}{ Active $\mathrm{C}$ pool } & \multicolumn{4}{|l|}{ Slow C pool } & \multicolumn{2}{|c|}{ Resistant C pool } \\
\hline & & $\operatorname{MgC~ha} a^{-1}$ & $\begin{array}{l}\text { Total } \\
\text { C (\%) }\end{array}$ & $\begin{array}{l}\text { Lab } \\
\text { MRT } \\
\text { (days) }\end{array}$ & $\begin{array}{l}\text { Field } \\
\text { MRT } \\
\text { (days) }^{2}\end{array}$ & $\mathrm{MgC} \mathrm{ha} a^{-1}$ & $\begin{array}{l}\text { Total } \\
\text { C ( } \%)\end{array}$ & $\begin{array}{l}\text { Lab } \\
\text { MRT } \\
\text { (years) }\end{array}$ & $\begin{array}{l}\text { Field } \\
\text { MRT } \\
\text { (years) }\end{array}$ & $\mathrm{MgCha} \mathrm{Ch}^{-1}$ & $\begin{array}{l}\text { Total } \\
\text { C }(\%)\end{array}$ \\
\hline \multirow{5}{*}{$\begin{array}{l}\text { NDSU LOTS } \\
\text { (4 year) } \\
\text { WSU IFSYS } \\
\text { (11 year) }\end{array}$} & Clean tillage & $0.35 \mathrm{a}^{3}$ & 1 & $26 \mathrm{a}$ & 73 & $18.5 \mathrm{a}$ & 44 & $8 \mathrm{a}$ & 22 & $23.6 \mathrm{a}$ & $55 \mathrm{a}$ \\
\hline & No tillage & $0.31 \mathrm{a}$ & 1 & $21 \mathrm{a}$ & 59 & $19.0 \mathrm{a}$ & 42 & $6 \mathrm{~b}$ & 17 & $26.0 \mathrm{a}$ & $57 \mathrm{a}$ \\
\hline & Mixed compost & $0.47 \mathrm{~A}$ & 1 & $25 \mathrm{~A}$ & 70 & $35.5 \mathrm{~A}$ & 48 & $8 \mathrm{~B}$ & 22 & $38.0 \mathrm{~A}$ & $51 \mathrm{~A}$ \\
\hline & Broiler litter & $0.33 \mathrm{~A}$ & 1 & $22 \mathrm{~A}$ & 62 & $28.2 \mathrm{~B}$ & 55 & $8 \mathrm{~B}$ & 22 & $23.0 \mathrm{~B}$ & $44 \mathrm{~B}$ \\
\hline & Pasture & $0.44 \mathrm{~A}$ & 1 & $30 \mathrm{~A}$ & 84 & $25.1 \mathrm{~B}$ & 55 & $9 \mathrm{~A}$ & 25 & $20.4 \mathrm{~B}$ & $44 \mathrm{~B}$ \\
\hline
\end{tabular}

\footnotetext{
${ }^{1}$ Curve fitting of the $\mathrm{CO}_{2} \mathrm{C}$ evolved per unit time was fit with a two-pool first-order constrained model using the SAS NLIN procedure (SAS (SAS 9.4)). The curves represent soil C pools at a $0-30 \mathrm{~cm}$ depth. The two soil depths, $0-15$ and $15-30 \mathrm{~cm}$ were not significantly different from one another.

2 Field MRTs were estimated from laboratory MRTs using a $\mathrm{Q}_{10}$ of 2.8.

3 Means within a column and field site with different letters are significantly different at $P=0.05$ level of significance.
}

Table 3. Measurements of hydrolyzable soil carbon $(\mathrm{HC})^{I}$ and permanganate oxidizable carbon (POXC) taken from a $0-30 \mathrm{~cm}$ soil depth.

\begin{tabular}{|c|c|c|c|c|c|c|}
\hline \multirow[b]{2}{*}{ Field site } & \multirow[b]{2}{*}{ Treatment } & \multicolumn{2}{|l|}{$\mathrm{HC}$} & \multicolumn{3}{|l|}{ POXC } \\
\hline & & $\mathrm{MgC} \mathrm{ha}=1$ & $\%$ Total C & $\mathrm{MgC} \mathrm{ha}=$ & $\%$ Total C & $\% \mathrm{HC}$ \\
\hline \multirow{5}{*}{$\begin{array}{l}\text { NDSU LOTS } \\
\text { (4 year) } \\
\text { WSU IFSYS } \\
\text { (11 year) }\end{array}$} & Clean tillage & $18.8 \mathrm{a}^{2}$ & $44 \mathrm{a}$ & $0.74 \mathrm{a}$ & $2 \mathrm{a}$ & $4 \mathrm{a}$ \\
\hline & No tillage & $19.4 \mathrm{a}$ & $43 \mathrm{a}$ & $0.84 \mathrm{a}$ & $2 \mathrm{a}$ & $4 \mathrm{a}$ \\
\hline & Mixed compost & $36.0 \mathrm{~A}$ & $49 \mathrm{~B}$ & $2.63 \mathrm{~A}$ & $4 \mathrm{~A}$ & $7 \mathrm{~A}$ \\
\hline & Broiler litter & $28.6 \mathrm{~B}$ & $56 \mathrm{~A}$ & $1.64 \mathrm{~B}$ & $3 \mathrm{~B}$ & $6 \mathrm{~B}$ \\
\hline & Pasture & $25.5 \mathrm{~B}$ & $56 \mathrm{~A}$ & $1.54 \mathrm{~B}$ & $3 \mathrm{~B}$ & $6 \mathrm{~B}$ \\
\hline
\end{tabular}

1 HC is defined as total soil organic carbon-non-hydrolyzable soil carbon.

2 ANOVA was run in SAS PROC GLM (SAS 9.4). Means within a column and field site with different letters are significantly different at $P=0.05$ by the LSMEANs procedure ( $P=0.05$ level of significance). The two soil depths, $0-15$ and $15-30 \mathrm{~cm}$ were not significantly different from one another. Therefore the means are averaged across soil depths $0-30 \mathrm{~cm}$.

\section{Nitrogen mineralization}

No significant differences in total soil $\mathrm{N}$ were observed among the IFSYS systems or between the LOTS tillage treatments (Table 1). A significant time interval $\times$ treatment interaction was observed in the cumulative $\mathrm{N}$ mineralized between the two organic tillage treatments in LOTS $(P=0.04)$ and among the three IFSYS organic management systems $(P=0.04)$ during the 360 day incubation (Table 4). Day 90 of the laboratory incubation approximates the end of a growing season and the optimum potential cumulative inorganic $\mathrm{N}$ available for crop growth. On day 90 of the soil incubation, prior no tillage management increased the cumlative inorganic $\mathrm{N}$ available relative to the clean tillage treatments taken from the LOTS field site. This difference, $54 \mathrm{~kg} \mathrm{~N} \mathrm{ha}^{-1}$, though not statistically significant may be agronomically relevant to plant $\mathrm{N}$ uptake. The inorganic $\mathrm{N}$ released on day 90 was higher in the mixed compost $\left(215 \mathrm{~kg} \mathrm{~N}^{-1}\right.$ soil) as compared with the pasture treatments $\left(150 \mathrm{~kg} \mathrm{~N} \mathrm{ha}^{-1}\right.$ soil). The 360 day incubation conducted with soils taken from the IFSYS field site revealed that the mixed compost and broiler litter treatments contained comparable and higher inorganic $\mathrm{N}$ relative to the pasture treatment by day $360(P<$ 0.0001 ), the end of the incubation.

\section{Linear regression analyses between $C$ and $N$ variables}

We related cumulative $\mathrm{CO}_{2}-\mathrm{C}$ evolved and inorganic $\mathrm{N}$ mineralized on day 90 of the incubation with hydrolyzable $\mathrm{C}$ and POXC via linear regression models. Both hydrolyzable $\mathrm{C}$ and $\mathrm{POXC}$ contributed significantly to the cumulative $\mathrm{CO}_{2}$ mineralized on day 90 from soil taken in the LOTS tillage treatments and soil from within the three organic management systems in IFSYS (Figs $1 \mathrm{a}$ and $1 \mathrm{~b}$, respectively). The amount of cumulative inorganic $\mathrm{N}$ and $\mathrm{CO}_{2}-\mathrm{C}$ released via mineralization on day 90 of the incubation is depicted in Fig. 2. Our data suggests that a significant amount of the $\mathrm{C}$ and $\mathrm{N}$ mineralized is 
Table 4. Cumulative inorganic $\left(\mathrm{NH}_{4}^{+}+\mathrm{NO}_{3}^{-}\right)-\mathrm{N}$ mineralized from a 360 day laboratory incubation taken from a $0-30 \mathrm{~cm}$ depth.

\begin{tabular}{|c|c|c|c|c|c|c|c|}
\hline \multirow[b]{2}{*}{ Field site } & \multirow[b]{2}{*}{ Treatment $^{2}$} & \multicolumn{6}{|c|}{ 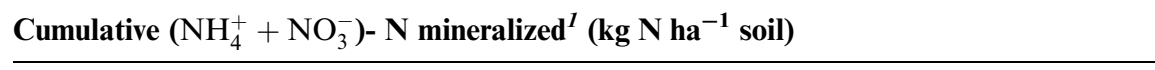 } \\
\hline & & Day 7 & Day 14 & Day 90 & Day 150 & Day 210 & Day 360 \\
\hline \multirow{5}{*}{$\begin{array}{l}\text { NDSU LOTS } \\
\text { (4 year) } \\
\text { WSU IFSYS } \\
\text { (11 year) }\end{array}$} & Clean tillage & $23.1 \mathrm{e}^{3}$ & $27.1 \mathrm{e}$ & 75.9 cde & 136 abcde & $163 \mathrm{abcd}$ & $225 \mathrm{ab}$ \\
\hline & No tillage & $38.0 \mathrm{de}$ & $46.9 \mathrm{de}$ & 130 bcde & $170 \mathrm{abcd}$ & $200 \mathrm{abc}$ & $265 \mathrm{a}$ \\
\hline & Mixed compost & $73.5 \mathrm{G}$ & $81.9 \mathrm{G}$ & $215 \mathrm{E}$ & $336 \mathrm{C}$ & $339 \mathrm{C}$ & $429 \mathrm{~A}$ \\
\hline & Broiler litter & $60.0 \mathrm{G}$ & $72.3 \mathrm{G}$ & $180 \mathrm{EF}$ & $275 \mathrm{D}$ & $351 \mathrm{BC}$ & $396 \mathrm{AB}$ \\
\hline & Pasture & $59.7 \mathrm{G}$ & $62.1 \mathrm{G}$ & $150 \mathrm{~F}$ & $221 \mathrm{E}$ & $284 \mathrm{D}$ & $318 \mathrm{CD}$ \\
\hline
\end{tabular}

${ }^{I}$ Cumulative $\left(\mathrm{NH}_{4}^{+}+\mathrm{NO}_{3}^{-}\right)$- $\mathrm{N}$ mineralized from a 360 day incubation at $25^{\circ} \mathrm{C}$ and $60 \%$ water-filled pore space.

2 ANOVA was run in SAS PROC MIXED (SAS 9.4). Time interval $\times$ treatment was significant $(P=0.04)$.

3 Means within a field site with different letters are significantly different at $P=0.05$ by LSMEANs procedure $(P=0.05$ level of significance). The two soil depths, $0-15$ and $15-30 \mathrm{~cm}$ were not significantly different from one another. Therefore the means are averaged across soil depths $0-30 \mathrm{~cm}$.

derived from the hydrolyzable $\mathrm{C}$ and POXC fractions and significantly less from SOC. Specifically, over $60 \%$ of the variation in the hydrolyzable $\mathrm{C}$ and POXC fractions could be explained by the quantity of $\mathrm{C}$ and $\mathrm{N}$ mineralized (Figs 1 and 3, respectively). The POXC and hydrolyzable $\mathrm{C}$ fractions explained over $80 \%$ of the variability in SOC measurements $\left(r^{2}=0.83\right.$ and $\left.r^{2}=0.88\right)$ (Figs $4 a$ and $4 \mathrm{~b}$, respectively). While only a little more than $50 \%$ of the variability in SOC could be explained by cumulative $\mathrm{C}$ mineralized as $\mathrm{CO}_{2}$ on day $90 \quad\left(r^{2}=0.58\right)$ (Fig. 4c). Although the tillage managments have comparable SOC and $\mathrm{CO}_{2}-\mathrm{C}$ released via mineralization, our data suggest that $\mathrm{C}$ and $\mathrm{N}$ are balanced/coupled in the no tillage system but potentially decoupled in the clean tillage management due to disturbance (Fig. 2a). The $\mathrm{C}$ and $\mathrm{N}$ appeared to be coupled in the mixed compost and pasture systems (Fig. 2b).

\section{Discussion}

\section{Estimates of the size and MRT of soil C pools}

Pasture systems have been shown to promote $\mathrm{C}$ accumulation while limiting the availability of inorganic $\mathrm{N}$ due to high density of roots, root exudation and lack of physical soil disturbance. Jones et al. (2006) investigated the effect of different organic and mineral $\mathrm{N}$ fertilizer treatments on $\mathrm{C}$ storage in temperate grasslands of Scotland. They found that addition of manure increased the $\mathrm{C}$ storage whereas mineral $\mathrm{N}$ fertilization had minimal effects on $\mathrm{C}$ storage. Intensive fertilizer use resulted in accelerated mineralization of SOM, i.e., decomposition of SOC and a reduction in soil C stocks. The build-up of SOM was directly affected by the amount of plant residues and animal inputs as well as the quality of these materials, all of which are influenced by management practices. In this experiment, the greater addition of $\mathrm{C}$ inputs that included resistant $\mathrm{C}$ from mixed compost additions likely resulted in the higher SOC in the mixed compost treatment despite the tillage disturbance that could have resulted in loss of SOC and was minimized in the pasture treatment. Teasdale et al. (2007) found that organic management practices that included additions of manure increased the SOC to a greater degree than no tillage systems receiving mineral fertilizer.

Our study is one of the few experiments that examines the effects of no tillage on organic management systems. There is ample evidence that SOC is higher in soils managed organically that receive nutrient additions like manure as compared with agricultural systems that receive synthetic fertilizer additions such as urea (ElHage Scialabba and Muller-Lindenlauf, 2010). However, organic producers in some cases have been importing inputs from off farm to supplement their fertility, thereby increasing SOC (Powlson et al., 2011). Yet, studies examining zero net input organic systems like mixed-livestock crop production systems where no imported inputs are utilized have also found that SOC concentrations were significantly higher under organic managed systems as compared with non-organic managed systems (Gattinger et al., 2012). We did not expect to have measurable differences in SOC due to tillage intensity in the LOTS treatments as the no tillage management was implemented for only 4 years prior to these measurements. Weil et al. (2003) compared the effect of conventional tillage versus no tillage in a wheat-based rotation at Mandan, ND, and could not find significant differences in SOC. Our and their findings may be due to the lowered plant biomass returned in the dry climatic conditions of western, ND that could reduce the rate of $\mathrm{C}$ decomposition and accumulation in soil.

Long-term incubations have been used by numerous researchers across a wide range of ecosystems to estimate the quantity and rate of $\mathrm{C}$ cycling (Paul et al., 1999; Fortuna et al., 2003). The amount of $\mathrm{CO}_{2}-\mathrm{C}$ mineralized per unit of SOC during a 360 day incubation is a mineralization quotient (Benbi et al., 2015), an indicator of the 

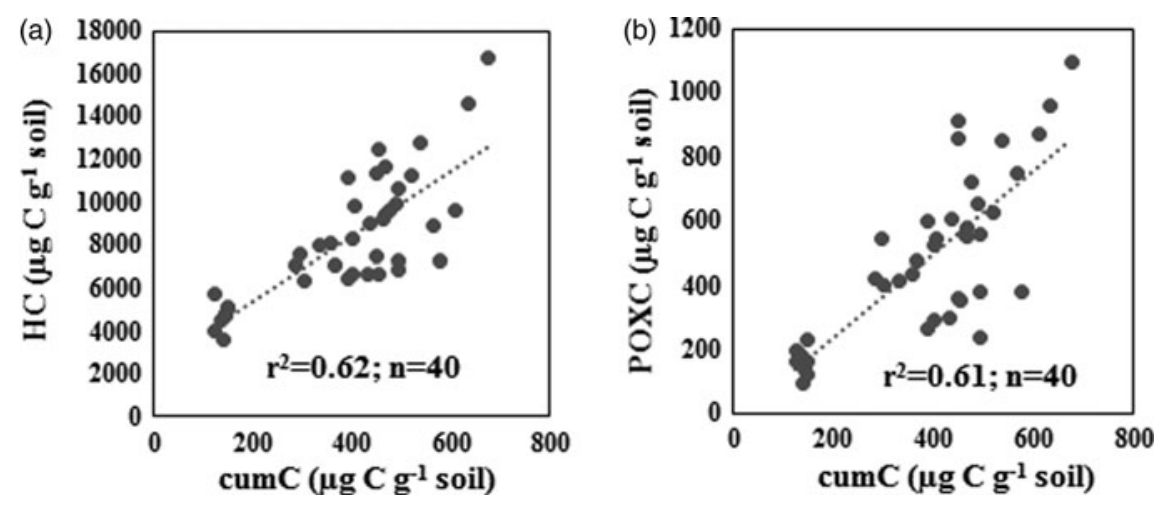

Figure 1. Interrelationship (linear regression) of cumulative $\mathrm{CO}_{2}-\mathrm{C}$ evolved on day 90 (cumC) with (a) hydrolyzable soil carbon (HC), and (b) permanganate oxidizable carbon (POXC) measured as coefficient of determination $\left(r^{2}\right)$ across the five different organic management systems and two soil depths, $0-15$ and $15-30 \mathrm{~cm}$.
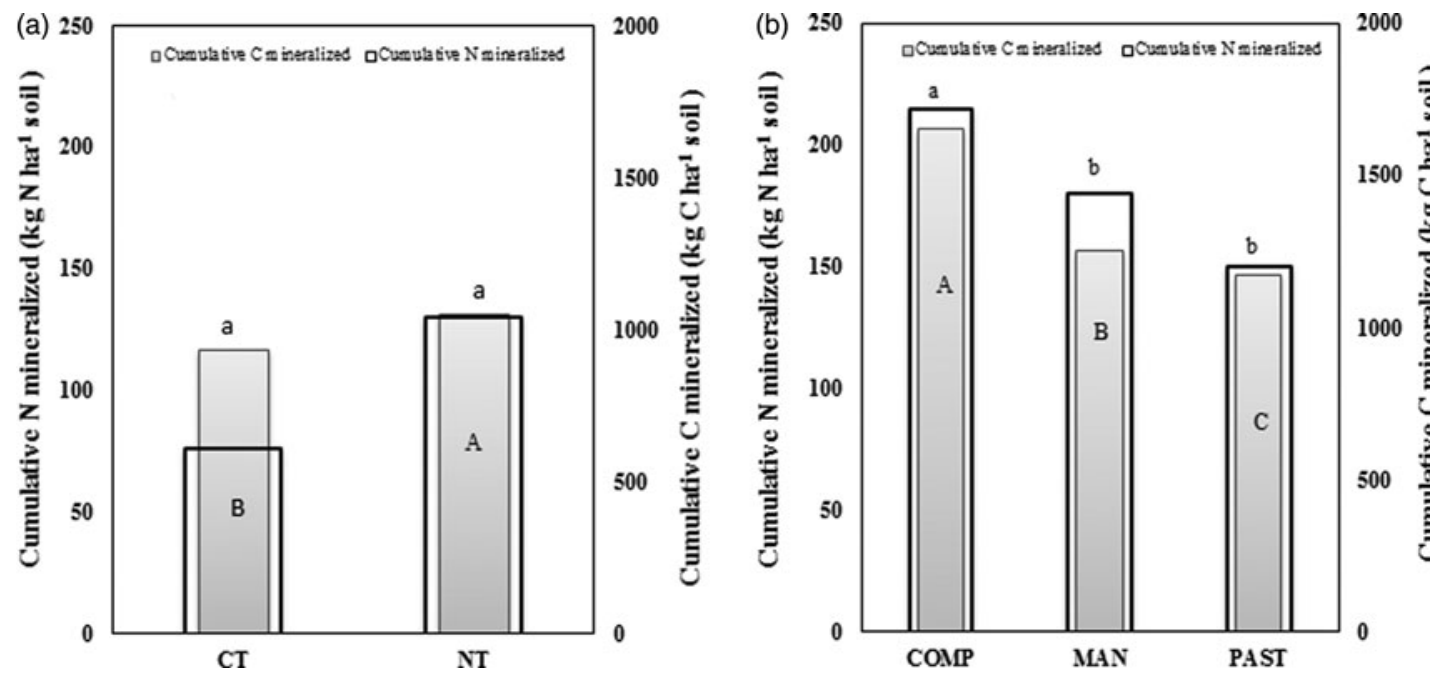

Figure 2. Cumulative $\mathrm{C}$ mineralized $\left(\mathrm{CO}_{2}-\mathrm{C}\right.$ evolved) and cumulative $\mathrm{N}$ mineralized $\left(\mathrm{NH}_{4}^{+}-\mathrm{N}+\mathrm{NO}-\mathrm{N}_{3}^{-} \mathrm{N}\right)$ on day 90 in (a) $\mathrm{Clean}$ tillage (CT) and No tillage (NT) in the LOTS field site and (b) Mixed compost (COMP), Broiler litter (MAN), Pasture (PAST) in the IFSYS field site. ANOVA was run in SAS PROC GLM (SAS 9.4). Within a field site, means with different letters and cases (lower case for cumulative $\mathrm{C}$ mineralized; upper case for cumulative $\mathrm{N}$ mineralized) are significantly different at $P=0.05$ by the LSMEANs procedure $(P=0.05$ level of significance) The two soil depths, $0-15$ and $15-30 \mathrm{~cm}$ were not significantly different from one another. Therefore the means are averaged across soil depths $0-30 \mathrm{~cm}$

efficiency of microorganisms to consume $\mathrm{C}$ rich substrate. In an incubation experiment with soils taken from temperate cropland receiving applications of mixed compost versus mineral $\mathrm{N}$ fertilizer for over a decade, $\mathrm{N}$ management did not have a significant effect on the amount of mineralizable $\mathrm{C}$ evolved as $\mathrm{CO}_{2} \mathrm{C}$ but did affect the amount of active and slow pool C (Fortuna et al., 2003). In contrast, Paul et al. (1999) observed higher $\mathrm{CO}_{2}$ evolution from soils taken from a no tillage, chemically fertilized corn/soybean rotation during a $\sim 1$ year long-term incubation experiment. Similarly, mineralizable $\mathrm{C}$ increased linearly with 10 years of $\mathrm{C}$ inputs from no tillage, intensively cropped systems (wheat/soybean double-crop) on a Fluventic Ustochrept (Franzluebbers et al., 1998). The greater amounts of SOC released as $\mathrm{CO}_{2}-\mathrm{C}$ from the mixed compost amended soil taken from the IFSYS field site may simply be a function of greater $\mathrm{C}$ additions added to the system in the form of mixed compost. However, a portion of the unexplained variation could be due to the difference in the extent of physical and chemical protection of $\mathrm{C}$ within soil aggregates (Benbi et al., 2015).

Cumulative $\mathrm{CO}_{2}-\mathrm{C}$ evolved during the 360 day $\mathrm{C}$ incubation was used to estimate the active and slow pools of $\mathrm{C}$, the pools most directly affected by BMP. These pools contribute biologically active $\mathrm{C}$ and constitute $\sim$ half of the $\mathrm{C}$ stocks in agronomic soils sampled to a $0-30 \mathrm{~cm}$ depth (Fortuna et al., 2003). In contrast, shifts in total SOC concentrations are long-term and are not necessarily directly linked to the biological activity and nutrient cycling of soils (Weil et al., 2003). Approximately half of the SOC in a $0-30 \mathrm{~cm}$ plow layer is comprised of $\mathrm{C}$ that 

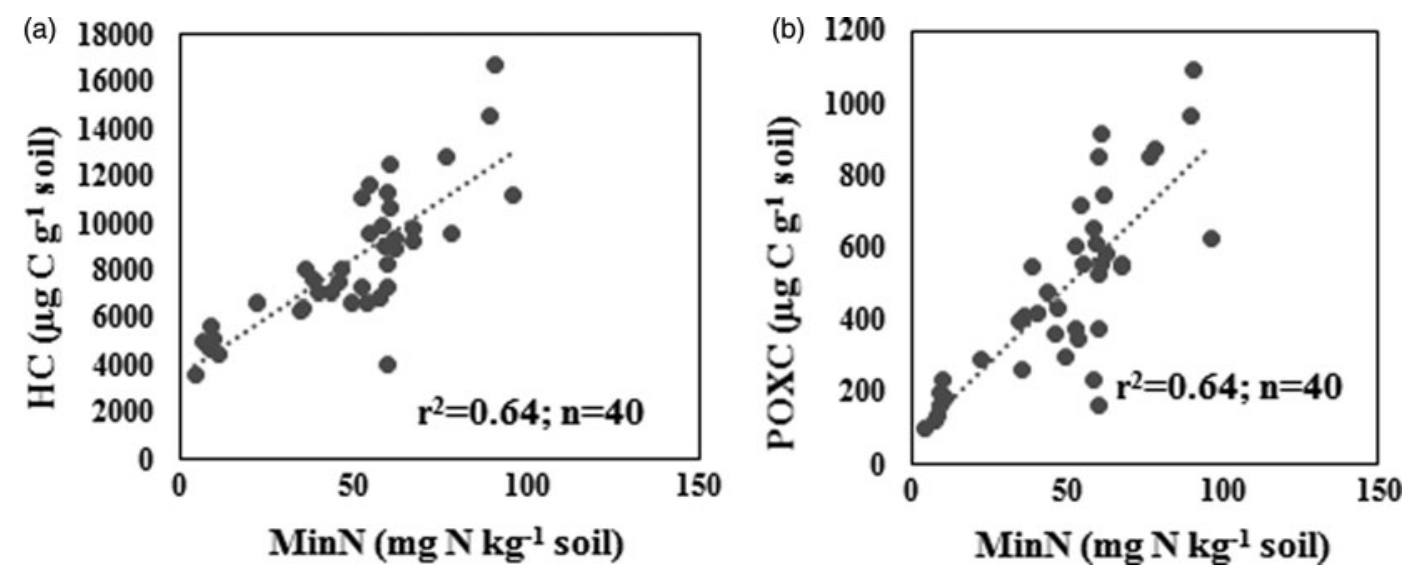

Figure 3. Interrelationship (linear regression) of cumulative $\mathrm{N}$ mineralized on day $90(\mathrm{MinN})$ with (a) hydrolyzable soil carbon (HC) and (b) permanganate oxidizable carbon (POXC) measured as coefficient of determination $\left(r^{2}\right)$ across the five different organic management systems and two depths, $0-15$ and $15-30 \mathrm{~cm}$.
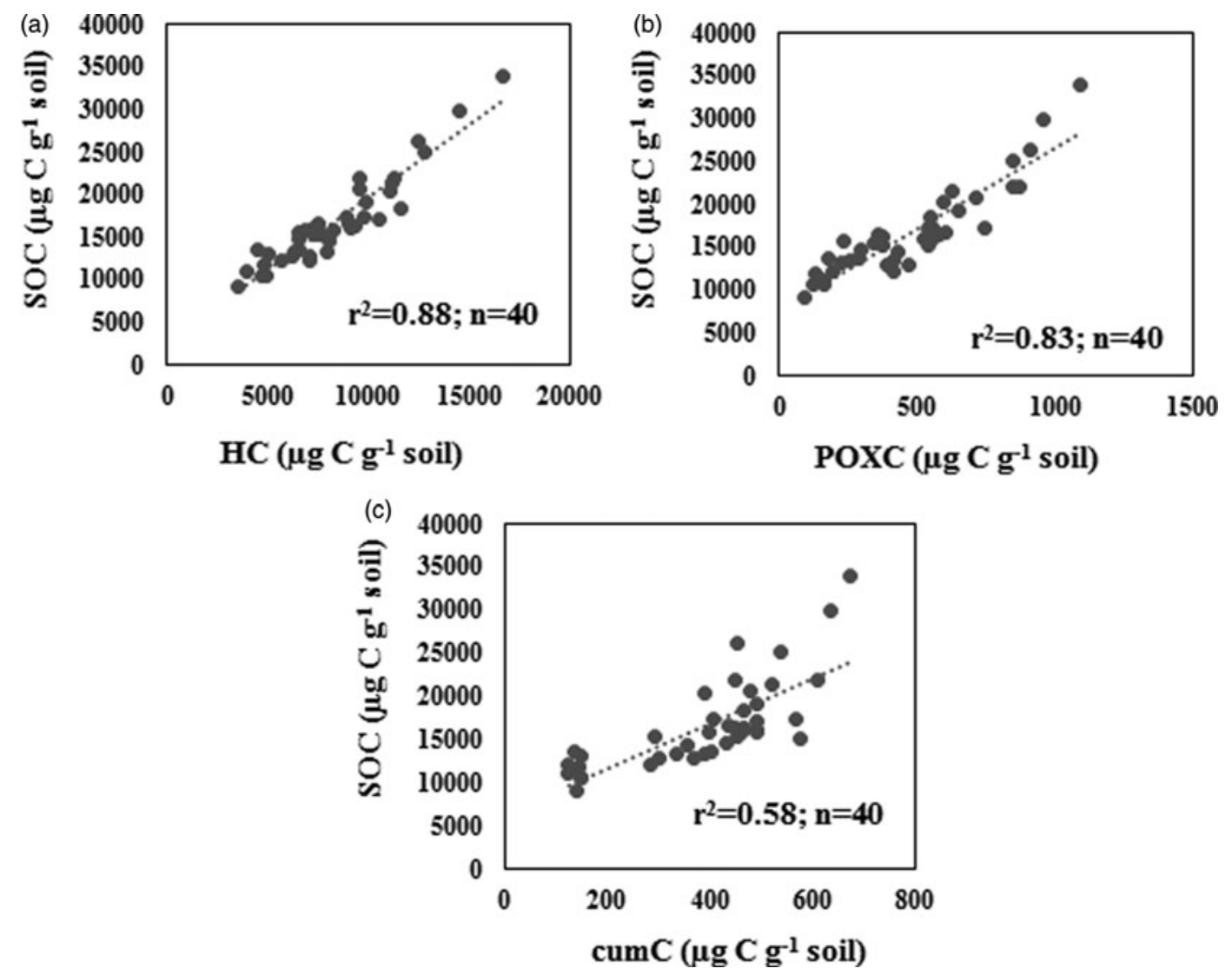

Figure 4. Interrelationship (linear regression) of total soil organic carbon (SOC) with (a) hydrolyzable C (HC), (b) permanganate oxidizable carbon (POXC) and (c) cumulative $\mathrm{CO}_{2}-\mathrm{C}$ evolved on day 90 measured as coefficient of determination $\left(r^{2}\right)$ across the five different organic management systems and two depths, $0-15$ and $15-30 \mathrm{~cm}$.

does not contribute to biologically active $\mathrm{C}$ and the remaining half of SOC has a mean residence time of years or decades (Fortuna et al., 2003; Paul et al., 2006). Fortuna et al. (2003) found that active C constituted less of the SOC in cropping systems fertilized with compost as compared with cropping systems that were fertilized with mineral $\mathrm{N}$. In this experiment, the active pools and MRTs within a field site and across depth were not significaly different. In a study conducted on a tropical grassland in Panama, the active pool of $\mathrm{C}$ comprised less than $1 \%$ of the SOC and had a MRT of 10 days (Schwendenmann and Pendall, 2008). 
Application of animal derived amendments and reductions in tillage increased the turnover rates of the slow pool in this study. The longer MRT of the active C pool in our organic pasture treatment may partially be due to the slower turnover of organic materials in temperate climates and differences in the methods employed in each experiment (Santruckowa et al., 2000). Lewis et al. (2011) found 14\% higher labile $\mathrm{C}$ in conservation tillage as compared with conventional tillage organic management systems. Tillage results in the shredding and incorporation of plant residues into the soil where the majority of microorganisms are located and the environment is more favorable for decomposition of $\mathrm{C}$. As a result, the clean tillage can be assumed to have less of the $\mathrm{C}$ rich substrate available to the microorganisms relative to the no tillage. This may explain in part the higher MRT of the slow pool $\mathrm{C}$ in the clean tillage relative to the no tillage treatment taken from the LOTS field site.

The contribution of resistant $\mathrm{C}$ to $\mathrm{CO}_{2}$ evolution during a $\sim 1$-year incubation was negligible (Paul et al., 1999). This and other studies have found that no tillage (Paul et al., 1999) and compost additions (Fortuna et al., 2003) contributed more $\mathrm{C}$ to the slow and resistant pools relative to the active pool of C. However, there are studies which suggest that organic inputs like the addition of farmyard manure can augment the active $\mathrm{C}$ pool relative to the slow and resistant pools of $C$ at $0-15 \mathrm{~cm}$ soil depth (Jha et al., 2012). Dissimilarities between the results of our study and those of Jha et al. (2012) may be due to differences in the models used to fit the $\mathrm{C}$ pools, or variations in nutrient contents and age of the manure between studies which would affect the amount of inorganic $\mathrm{N}$ and biologically active $\mathrm{C}$ available as well as the biochemical constituents of the manures.

The adoption of organic management practices that include addition of organic amendments (in the form of mixed compost) and no tillage or low disturbance pasture treatments have the potential to reduce $\mathrm{CO}_{2}$ emission per unit of SOC since these BMP foster $\mathrm{C}$ sequestration and contribute less labile $\mathrm{C}$ as a portion of SOC (Dou et al., 2008). In addition, the presence of higher concentrations of resistant $\mathrm{C}$ derived from mixed compost additions with MRTs of potentially hundreds or thousands of years (Paul et al., 1997) could reduce $\mathrm{C}$ lost as $\mathrm{CO}_{2}$ in these organic management systems. Although estimates of the size of slow pool $\mathrm{C}$ were comparable between the clean and no tillage treatments, variations in the MRT of the slow pool with tillage treatment may reflect a shift in the potential to accrue and or sequester $\mathrm{C}$ in these systems. The model used to estimate the first-order kinetics of $\mathrm{C}$ mineralization allows us to assess both the size and turnover rate of the active and slow pools of $\mathrm{C}$ while the rapid assessment methods used in this study, hydrolyzable C, POXC and SOC cannot be used to estimate MRT. Our three pool model is a valuable tool for assessment of short and long-term shifts in SOC resulting from implementation of BMP.

\section{Rapid measures of soil $C$ as a proxy for active and slow pools of $\mathrm{C}$}

The three pool first-order model is an effective means of partitioning $\mathrm{C}$ into pools that cycle on a seasonal and long-term basis but is time and resource intensive. Therefore, relating the long-term incubation measurements with rapid measures of soil $\mathrm{C}$ fractions such as hydrolyzable $\mathrm{C}$ and POXC was useful as a means of comparing different organic management systems. The hydrolyzable $\mathrm{C}$ represents the largest labile fraction of $\mathrm{C}$ (McLauchlan and Hobbie, 2004). Dou et al. (2008) found that hydrolyzable $\mathrm{C}$ comprised a larger portion of SOC $(59-72 \%)$ in a tilled wheat field receiving mineral $\mathrm{N}$ fertilizer.

Like hydrolyzable $\mathrm{C}$, analysis of the POXC fraction is simple, quick and inexpensive. The POXC fraction approximates the active $\mathrm{C}$ pool and a portion of the slow $\mathrm{C}$ pool estimated via the three pool $\mathrm{C}$ model. The POXC fraction constitutes a smaller portion of estimated slow pool $\mathrm{C}$ contained in the hydrolysable $\mathrm{C}$ fraction. Weil et al. (2003) developed a modified POXC protocol with the intent of incorporating the measuement into the Natural Resource Conservation Service's soil health test kit. The measure is a proxy of reactive $\mathrm{C}$ and is a sensitive measure of soil health reflecting the effects of BMP and land use. The fractions of SOM from which POXC originates include fresh organic material, soil microbial biomass, particulate organic matter and other easily metabolized organic compounds, such as carbohydrates (sugars) and proteins (amino acids), as well as C loosely bound to soil minerals. The MRT of the POXC fraction is short in comparison with the resistant $\mathrm{C}$ fraction, which has a turnover rate of several hundreds to thousands of years (Weil et al., 2003).

Previous studies have indicated that the application of mixed compost or manure to a crop rotation increases the POXC content in the soil (Lucas and Weil, 2012; Culman et al., 2013). Similar results were observed for the POXC fraction with different tillage intensities in a chemically fertilized wheat-sunflower (Helianthus annuus L.)-fodder pea cropping system (Lopez-Garrido et al., 2014). Weil et al. (2003) reported that the POXC fraction was sensitive to long-term tillage management (tilled versus minimum tilled) in a wheat-based rotation in North Dakota.

\section{Nitrogen mineralization dynamics}

The use of a growing degree day calculation allowed for the correlation of incubation time intervals with growth stages of crops grown in the field trials and took into account the effect of temperature on $\mathrm{C}$ and $\mathrm{N}$ mineralization (Lawson et al., 2012). A recent study on the IFSYS plots revealed that the addition of mixed compost to the soils increased the size $\left(102 \pm 17 \mathrm{mg} \mathrm{N} \mathrm{kg}^{-1}\right)$ and the MRT ( $66 \pm 30$ days) of the pool of mineralizable 
organic $\mathrm{N}$ in soil (Cogger et al., 2016). Previous studies have found increases in the pool of potentially mineralizable $\mathrm{N}$ in soils where compost was added (Fortuna et al., 2003; Spargo et al., 2011).

\section{Soil health measurements are indicators of the coupling and decoupling of $C$ and $N$}

Our regression responses between individual $\mathrm{C}$ fractions and mineral $\mathrm{N}$ verify that variations in SOC cannot be measured via the active $\mathrm{C}$ fraction $\left(\mathrm{CO}_{2}\right.$ evolved) but require a fraction that contains both active and a portion of slow pool $\mathrm{C}$ (HC and POXC). Although there is a significant correlation between hydrolyzable $\mathrm{C}$ and SOC, hydrolysable $\mathrm{C}$ is a biologically active $\mathrm{C}$ fraction associated with the release of nutrients while $\sim 40$ $60 \%$ of SOC is not biologically active. Therefore, SOC is a less sensitive biological indicator of soil health relative to hydrolyzable $\mathrm{C}$ or POXC because shifts in biologically active $\mathrm{C}$ resulting from adoption of BMP are likely to be concealed for several years due to the presence of $\sim 40$ $60 \%$ nonhydrolyzable C in SOC. As previously discussed, active carbon fractions account for over $80 \%$ of the variability in SOC measurements because release of nutrients is associated with active $\mathrm{C}$ fractions. The $\mathrm{HC}$ and POXC contain minimal resistant $\mathrm{C}$. Therefore these fractions are well correlated with SOC but provide additional information with respect to biologically active $\mathrm{C}$ and inorganic $\mathrm{N}$ and their response to BMP.

Both HC and POXC contain biologically active fractions but $\mathrm{HC}$ contains $\sim 10$ times more biologically active soil $\mathrm{C}$ relative to $\mathrm{POXC}$. In addition, how much active versus slow pool $\mathrm{C}$ is contained in the POXC fraction is highly dependent upon the ability of the permanganate to oxidize a wide range of organic compounds containing variable biochemical components and the degree of chemical protection of these compounds, which is partly determined by soil texture. In contrast, the acid hydrolysis reaction removes nearly all the biologically active $\mathrm{C}$ from soil, although some lignin $\mathrm{C}$ has been shown to resist acid digestion (Paul et al., 2001). Therefore, $\mathrm{HC}$ is the less variable measure of active $\mathrm{C}$ but requires knowledge of SOC content as $\mathrm{HC}$ is equal to SOC minus nonhydrolyzable $\mathrm{C}$. We recommend coupling acid hydrolysis and SOC measurements to determine the impact of a BMP on the quantity of biologically active and resistant $\mathrm{C}$ contained in SOC. The mixed compost additions increased both biologically active $\mathrm{C}$ and nonhydrolyzable $\mathrm{C}$ but contributed greater $\mathrm{C}$ to the resistant fraction (nonbiological).

The application and calibration of a labile soil $\mathrm{C}$ test such as hydrolyzable $\mathrm{C}$ and POXC could be used as a useful management tool for organic farmers to predict shifts in $\mathrm{N}$ fertility and soil health. The mineralization of $\mathrm{C}$ and $\mathrm{N}$ have been shown to be good indicators of crop yield and biomass (Culman et al., 2013). Lucas \& Weil (2012) found that POXC could be used to predict crop yield and response to SOM management when winter rye was planted as a cover crop in a no tillage system. Thus, the hydrolyzable $\mathrm{C}$ and POXC can potentially serve as indicators of $\mathrm{N}$ availability, $\mathrm{CO}_{2}$ evolution and crop yield in organic management systems.

A similar relationship between hydrolyzable $\mathrm{C}$ and SOC was obtained by Dou et al. (2008) while examining the sensitivity of labile carbon pools in small grain based cropping systems fertilized with mineral $\mathrm{N}$. The hydrolyzable $\mathrm{C}$ may be better related to SOC due to the greater quantity of SOC contained in the hydrolyzable $\mathrm{C}$ fraction relatively to that of mineralizable C. Several other studies verify a significant positive interaction between POXC and SOC (Weil et al., 2003; Culman et al., 2012). This might be due to similar methodologies used to estimate SOC and POXC, which are based on the oxidation of $\mathrm{C}$ fractions contained in both SOC and the POXC fraction (Culman et al., 2013).

Organic management systems reflect the concept that $\mathrm{N}$ is stabilized in direct association with $\mathrm{C}$ (Bowles et al., 2015; Margenot et al., 2015; Bhowmik et al., 2016). The amount of reactive $\mathrm{N}$ and active $\mathrm{C}$ are reduced when $\mathrm{N}$ is coupled with $\mathrm{C}$ of any type but particularly when $\mathrm{N}$ is bound with $\mathrm{C}$ in humic compounds such as in the IFSYS mixed compost amendment that turns over more slowly and has a wider $\mathrm{C}: \mathrm{N}$ ratio than broiler litter and plant residues (Bhowmik et al., 2016). In this experiment, additions of mixed compost and limited disturbace in the pasture system fostered the retention of $\mathrm{C}$ and affected the MRT of C pools. Specifically, adoption of these BMP facilitated the flow of $\mathrm{C}$ into the slow pool (contains accessible nutrients) while reducing the quantity of $\mathrm{C}$ in the active pool (a source of $\mathrm{CO}_{2}$, a GHG) without fostering losses of reactive $\mathrm{N}$. The enrichment of slow pool $\mathrm{C}$ and comparable total soil $\mathrm{N}$ among the IFSYS treatments in these organic agroecosystems reflects improvement in soil health and fertility resulting from the adoption of BMP.

\section{Conclusions}

Our research addresses the effects of BMP (tillage, application of organic amendments, livestock integration and land use) on the cycling of $\mathrm{C}$ and $\mathrm{N}$ in five different organic agroecosystems. Adoption of the above BMP in organic management systems reduced the partitioning of $\mathrm{C}$ to the active pool while augmenting the slow pool C. These pools are associated with the potentially mineralizable $\mathrm{N}$ supplied by residues, amendments and SOM affecting the concentration and release of mineral $\mathrm{N}$ required for crop $\mathrm{N}$ demand. Specifically, hydrolyzable $\mathrm{C}$ and POXC were significantly related with the cumulative $\mathrm{N}$ mineralized on day 90 of the incubation (the approximate length of the field season in growing degree days). Previous studies in which POXC was used as the sole indicator to predict biologically active $\mathrm{C}$ gave less 
consistent results due to differences in the types of $\mathrm{C}$ constituents contained in the POXC fraction.

This study couples POXC with hydrolyzable $\mathrm{C}$ (C that can undergo hydrolysis reactions) as soil health indicators for rapid (within 2-4 year) assessment of shifts in biologically active $\mathrm{C}$ resulting from change in management. Specifically, these soil health measurements could be employed to assess the impact of BMP on C sequestration and soil fertility prior to shifts in SOC. Although both measurements could be completed by a soil testing unit within a few weeks, we recommend coupling acid hydrolysis and SOC measurements to determine the impact of a $\mathrm{BMP}$ on the quantity of biologically active and resistant $\mathrm{C}$ rather than POXC. Both $\mathrm{HC}$ and POXC contain biologically active $\mathrm{C}$ fractions. However, $\mathrm{HC}$ measurements are more consistent as POXC contains $\sim 10$ times less biologically active soil $\mathrm{C}$ and POXC concentrations are partly dependent upon the degree to which the $\mathrm{C}$ is chemically protected, which is primarily determined by soil texture. Future research should include soils from a range of textures, climates and organic agroecosystems in order to assess the value of using POXC and hydrolyzable $\mathrm{C}$ fractions to predict shifts in the size of active and slow $\mathrm{C}$ pools routinely estimated via a three pool nonlinear model. After careful calibration, POXC and hydrolyzable $\mathrm{C}$ may provide guidance to organic growers enabling them to align their organic management practices with that of the USDA-Natural Resource Conservation Service's recommendations for potential future carbon credit payments.

\section{Supplementary Material}

The supplementary material for this article can be found at https://doi.org/10.1017/S1742170516000429

Acknowledgements. This project was supported by the Organic Transitions Competitive Grant no. 2011-51106-20659 from the United States Department of Agriculture (USDA) National Institute of Food and Agriculture (NIFA).

\section{References}

Andresen, J. 2010. Calculation of Baskerville-Emin ('BE') Growing Degree Days. Michigan State University. Available at Web site http://www.maes.msu.edu/nwmihort/ be_method.pdf (verified 2 March 2016).

Azeez, G. 2009. Soil Carbon and Organic Farming. A Review on the Relationship Between Agriculture and Soil Carbon Sequestration, and How Organic Farming Can Contribute to Climate Change Mitigation and Adaptation. Soil Association, Bristol, UK. Available at Website http://www. soilassociation.org (verified 10 March 2016).

Benbi, D.K., Brar, K., Toor, A.S., and Songh, P. 2015. Total and labile pools of soil organic carbon in cultivated and undisturbed soils in northern India. Geoderma 237:149-158.
Berthrong, S.T., Buckley, D.H., and Drinkwater, L.E. 2013. Agricultural management and labile carbon additions affect soil microbial community structure and interact with carbon and nitrogen cycling. Microbial Ecology 66:158-170.

Bhowmik, A., Fortuna, A.M., Cihacek, L., Bary, A., and Cogger, C.G. 2016. Use of biological indicators of soil health to estimate reactive nitrogen dynamics in long-term organic vegetable and pasture systems. Soil Biology and Biochemistry 103:308-319.

Bowles, T.M., Hollander, A.D. Steenwerth, K., and Jackson, L.E. 2015. Tightly-coupled plant-soil nitrogen cycling: comparison of organic farms across an agricultural landscape. PLoS ONE 10(6):e0131888. doi: 10.1371/journal.pone.0131888.

Bremner, J.M. 1960. Determination of nitrogen in soil by the Kjeldahl method. Journal of Agricultural Science 55:11-33.

Buyanovsky, G.A., Aslam, M., and Wagner, G.H. 1994. Carbon turnover in soil physical fractions. Soil Science Society of America Journal 58:1167-1173.

Cogger, C.G., Bary, A.I., Myhre, E.A., Fortuna, A., and Collins, D.P. 2016. Soil physical properties, nitrogen, and crop yield in organic vegetable production systems. Agronomy Journal 108:1142-1154.

Culman, S.W., Snapp, S.S., Freeman, M.A., Schipanski, M.E., Beniston, J., Lal, R., Drinkwater, L.E., Franzluebbers, A.J., Glover, J.D., Grandy, A.S., Lee, J., Six, J., Maul, J.E., Mirksy, S.B., Spargo, J.T., and Wander, M.M. 2012. Permanganate oxi-dizable carbon reflects a processed soil fraction that is sensitive to management. Soil Science Society of America Journal 76:494-504.

Culman, S.W., Snapp, S.S., Green, J.M., and Gentry, L.E. 2013. Short- and long-term labile soil carbon and nitrogen dynamics reflect management and predict corn agronomic performance. Agronomy Journal 105:493-502.

Dou, F., Wright, A.L., Hons, F.M. 2008. Sensitivity of labile soil organic carbon to tillage in wheat-based cropping systems. Soil Science Society of America Journal 72:1445-1453.

Drinkwater, L.E., Wagoner, P., and Sarrantonio, M. 1998. Legume-based cropping systems have reduced carbon and nitrogen losses. Nature 396:262-265.

El-Hage Scialabba, N., and Muller-Lindenlauf, M. 2010. Organic agriculture and climate change. Renewable Agriculture and Food Systems 25:158-169.

Ellert, B.H., and J.R. Bettany. 1988. Comparison of kinetic models for describing net sulfur and nitrogen mineralization. Soil Science Society of America Journal 52:1692-1702.

Fließbach, A., Oberholzer, H., Gunst, L., and Paul, M. 2007. Soil organic matter and biological soil quality indicators after 21 years of organic and conventional farming. Agriculture, Ecosystems and Environment 118:273-284.

Fortuna, A., Harwood, R., Kizilkaya, K., and Paul, E.A. 2003. Optimizing nutrient availability and potential carbon sequestration in an agroecosystem. Soil Biology and Biochemistry 35:1005-1013.

Franzluebbers, A.J. 2005. Soil organic carbon sequestration and agricultural greenhouse gas emissions in the southeastern USA. Soil and Tillage Research 83:120-147.

Franzluebbers, A.J., Hons, F.M., and Zuberer, D.A. 1998. In situ and potential $\mathrm{CO}_{2}$ evolution from a fluventic Ustochrept in southcentral Texas as affected by tillage and crop management. Soil and Tillage Research 47:303-308.

Gaskell, M. and Smith, R. 2007. Nitrogen sources for organic vegetable crops. HortTechnology 17:431-441. 
Gattinger, A., Muller, A., Haeni, M., Colin, S., Fliessbach, A., Buchmann, N., Mader, P., Stolze, M., Smith, P., El-Hage Scialabba, N., and Niggli, U. 2012. Enhanced top soil carbon stocks under organic farming. Proceedings of the National Academy of Sciences 109:18226-18231.

Grossman, R.B. and Reinsch, T.G. 2002. Bulk density and linear extensibility. In G.S. Campbell, R. Hosrton, and W.A. Jury (eds.). Methods of Soil Analysis. Part 4: Physical Methods. Soil Science Society of America, Madison, WI. p. 207-210.

Iqbal, J., Hu, R., Lin, S., Ahamadou, B., and Feng, M. 2009. Carbon dioxide emissions from Ultisol under different land uses in mid-subtropical China. Geoderma 152:63-73.

Janzen, H.H., Campbell, C.A., Izaurralde, R.C., Ellert, B.H., Juma, N., McGill, W.B. and Zentner, R.P. 1998. Management effects on soil C storage on the Canadian prairies. Soil and Tillage Research 47:181-195.

Jha, P., De, A., Lakaria, B.L., Biswas, A.K., Singh, M., Reddy, K.S., and Rao, A.S. 2012. Soil carbon pools, mineralization and fluxes associated with land use change in vertisols of Central India. National Academy Science Letters 35:475483.

Johnson, J.M.F., Franzluebbers, A.J., Weyers, S.L., and Reicosky, D.C. 2007. Agricultural opportunities to mitigate greenhouse gas emissions. Environmental Pollution 150: 107-124.

Jones, S.K., Rees, R.M., Kosmas, D., Ball, B.C., and Skiba, U.M. 2006. Carbon sequestration in a temperate grassland; management and climatic controls. Soil Use and Management 22:132-142.

Karlen, D.L., M.J. Mausbach, J.W. Doran, R.G. Cline, R.F. Harris, and Schuman, G.E. 1997. Soil quality: A concept, definition, and framework for evaluation. Soil Science Society of American Journal 61:4-10.

Katterer, T., Reichstein, M., Andren, O., and Lomander, A. 1998. Temperature dependence of organic matter decomposition: A critical review using literature data analyzed with different models. Biology and Fertility of Soils 27:258-262.

Lawson, A., Fortuna, A.M., Cogger, C., Bary, A., and Stubbs, T. 2012. Nitrogen contribution of rye-hairy vetch cover crop mixtures to organically grown sweet corn. Renewable Agriculture and Food Systems 28:59-69.

Lewis, D.B., Kaye, J.P., Jabbour, R., and Barbercheck, M.E. 2011. Labile carbon and other soil quality indicators in two tillage systems during transition to organic agriculture. Renewable Agriculture and Food Systems 26:342-353.

Lopez-Garrido, R., Madejon, E., Murillo, J.M., and Moreno, F. 2011. Soil quality alteration by mouldboard ploughing in a commercial farm devoted to no-tillage under Mediterranean conditions. Agriculture, Ecosystems and Environment 140:182-190.

Lopez-Garrido, R., Madejon, E., Leon-Camacho, M., Giron, I., Moreno, F., and Murillo, J.M. 2014. Reduced tillage as an alternative to no-tillage under Mediterranean conditions: A case study. Soil and tillage Research 140:40-47.

Lucas, S.T., and Weil, R.R. 2012. Can a labile carbon test be used to predict crop responses to improved soil organic matter management? Agronomy Journal 104:1160-1170.

Margenot, A.J., Caderon, F.J., Bowles, T.M., Parikh, S.J., and Jackson, L.E. 2015. Soil organic matter functional group composition in relation to organic carbon, nitrogen, and phosphorus fractions in organically managed tomato fields. Soil Science Society of America Journal 79:772-782.
McLauchlan, K.K., and Hobbie, S.E. 2004. Comparison of labile soil organic matter fractionation techniques. Soil Science Society of America Journal 68:1616-1625.

Melero, S., Lopez-Garrido, R., Madejon, E., Murillo, J.M., Vanderlinden, K., Ordonez, R., and Moreno, F. 2009a. Long-term effects of conservation tillage on organic fractions in two soils in southwest of Spain. Agriculture, Ecosystems and Environment 133:68-74.

Melero, S., Lopez-Garrido, R., Murillo, J.M., and Moreno, F. 2009b. Conservation tillage: Short- and long-term effects on soil carbon fractions and enzymatic activities under Mediterranean conditions. Soil and Tillage Research 104: 292-298.

Motavalli, P.P., Palm, C.A., Parton, W.J., Elliott, E.T., and Frey, S.D. 1994. Comparison of laboratory and modeling simulation methods for estimating soil carbon pools in tropical forest soils. Soil Biology and Biochemistry 26:935-944.

Paul, E.A., Follett, R.F., Leavitt, S.W., Halvorson, A., Peterson, G.A., and Lyon, D.J. 1997. Radiocarbon dating for determination of soil organic matter pool sizes and dynamics. Soil Science Society of America Journal 61: 1058-1067.

Paul, E.A., Harris, D., Collins, H.P., Schulthess, U., and Robertson, G.P. 1999. Evolution of $\mathrm{CO}_{2}$ and soil carbon dynamics in biologically managed, row-crop agroecosystems. Applied Soil Ecology 11:53-65.

Paul, E.A., Morris, J.S., and Bohm, S. 2001. The determination of soil $\mathrm{C}$ pool sizes and turnover rates: biophysical fractionation and tracers. In R. Lal, J.M. Kimble and R.F. Follett (eds.). Assessment Methods for Soil Carbon Pools. CRC Press, Boca Raton, FL. p. 193-203.

Paul, E.A., Morris, S.J., Conant, R.T., and Plante, A.F. 2006. Does the acid hydrolysis-incubation method measure meaningful soil organic carbon pools? Soil Science Society of America Journal 70:1023-1035.

Powlson, D.S., Whitmore, A.P., and Goulding, K.W.T. 2011. Soil carbon sequestration to mitigate climate change: A critical re-examination to identify the true and the false. European Journal of Soil Science 62:42-55.

Santruckowa, H., Bird, M.I., and Lloyd, L. 2000. Microbial processes and carbon-isotope fractionation in tropical and temperate grassland soils. Functional Ecology 14:108-114.

Schwendenmann, L., and Pendall, E. 2008. Response of soil organic matter dynamics to conversion from tropical forest to grassland as determined by long-term incubation. Biology and Fertility of Soils 44:1053-1062.

Six, J., Conant, R.T., Paul, E.A., and Paustian, K. 2002. Stabilization mechanisms of soil organic matter: Implications for C-saturation of soils. Plant and Soil 241: 155-176.

Spargo, J.T., Cavigelli, M.A., Mirsky, S.B., Maul, J.E., and Meisinger, J.J. 2011. Mineralizable soil nitrogen and labile soil organic matter in diverse long-term cropping systems. Nutrient Cycling in Agroecosystems 90:253-266.

Teasdale, J.R., Coffman, C.B., and Mangum, R.W. 2007. Potential long-term benefits of no- tillage and organic cropping systems for grain production and soil improvement. Agronomy Journal 99:1297-1305.

Weil, R.R., Islam, K.R., Stine, M.A., Gruver, J.B., and SamsonLiebig, S.E. 2003. Estimating active carbon for soil quality assessment: A simplified method for laboratory and field use. American Journal of Alternative Agriculture 18:3-17. 